\title{
Monitoring of pulp mill effluents in the coastal waters of North Estonia
}

\author{
Ü. Suursaar, R. Aps, G. Martin, A. Põllumäe \& K. Kaljurand \\ Estonian Marine Institute, University of Tartu, Estonia
}

\begin{abstract}
In September 2006, AS Estonian Cell, a brand new aspen pulp mill was opened near Kunda. Partly due to ill memories of past environmental problems in the region, the environmental standards for the plant were set very high. The factory features sulphur free production, chlorine free bleaching and low fresh water consumption. High requirements were put on environmental monitoring. The purified wastewater is conducted via a pipe into the Baltic Sea at a depth of $10 \mathrm{~m}$, about $1.5 \mathrm{~km}$ from the coast, and monitoring of the fate and possible effects of the effluents was launched. The monitoring programme includes repeated water and biota samplings and a study of the hydrodynamic regime. It appeared that due to good dilution conditions, the impact of the factory on the abiotic environmental components is barely visible in the background of normal seasonal and storm-generated variability. There may be small changes in bottom organisms in the vicinity of the outlet, though. The preliminary results basically confirm that the impact of the pulp mill on the coastal sea is not large and the environmental risks are generally well handled.
\end{abstract}

Keywords: pulp industry, pollution dispersion, RDCP, resuspension, upwelling, coastal jet.

\section{Introduction}

Estonia, like its forest-rich neighbouring countries Finland, Sweden and Russia, has long traditions in the pulp and paper industry. The first paper mill in Estonia (Tallinn, Härjapea) was operating between 1662-1710.

Around the Gulf of Finland, the major areas of pulp and paper industry are the Kotka region in Finland and St. Petersburg in Russia. In North Estonia, large pulp and paper mills existed in Tallinn and Kehra and a smaller one in Kohila. They all discharged, either directly or via rivers, to the Gulf of Finland. The 
closure of these mills in the 1990s was a result of changing economical prospects after regaining independence, but also of altered environmental requirements. The Tallinn mill had an annual production of about $68000 \mathrm{t}$ of sulphite cellulose, and the Kehra mill had 52000 t of sulphate cellulose. Until 1989, untreated waste from the Tallinn mill was discharged to the southern part of the Tallinn Bay, which was the most polluted zone along the Estonian coastline in those days [1]. The Bay featured very low $\mathrm{pH}$, low oxygen and high $\mathrm{N}_{-} \mathrm{NH}_{4}$ content. The quality of the water also failed markedly by organoleptic standards.

Evidently, several adverse aspects of pulp mill pollution were not monitored then. They would have required extensive scientific effort. For example, it appeared that the pulp and paper industry is one of the main producers of the chlorinated compounds (usually quantified as organic sum parameters such as EOX and AOX) found in the Baltic Sea [2]. These compounds are persistent, toxic and they tend to bioaccumulate [3]. Today, most pulp mills utilize a chlorine-free bleaching process. However, about $50 \%$ of the total organochlorine inputs from pulp mills since the early 1940s still reside in the Baltic Sea - mainly in the bottom sediments [4].

The aim of the paper is: 1) to give a brief overview of the environmental problems related to the pulp industry in Estonia; 2) to describe the monitoring activities for the effluents of a new pulp mill near Kunda and to discuss the first scientific results of these efforts.

\section{Study area and overview of the Kunda pulp mill}

The North Estonian coastal sea stretches for about $250 \mathrm{~km}$ from west to east along the Gulf of Finland (Fig.1), which has an area of $29500 \mathrm{~km}^{2}$ and average depth of $37 \mathrm{~m}$. The Gulf receives a relatively large pollution load both from rivers (Neva, Narva, Kymijoki), as well as from industries and municipalities $[5,6]$. Along the Estonian coast, the most polluted regions are the Bays of Narva, Tallinn and Muuga.

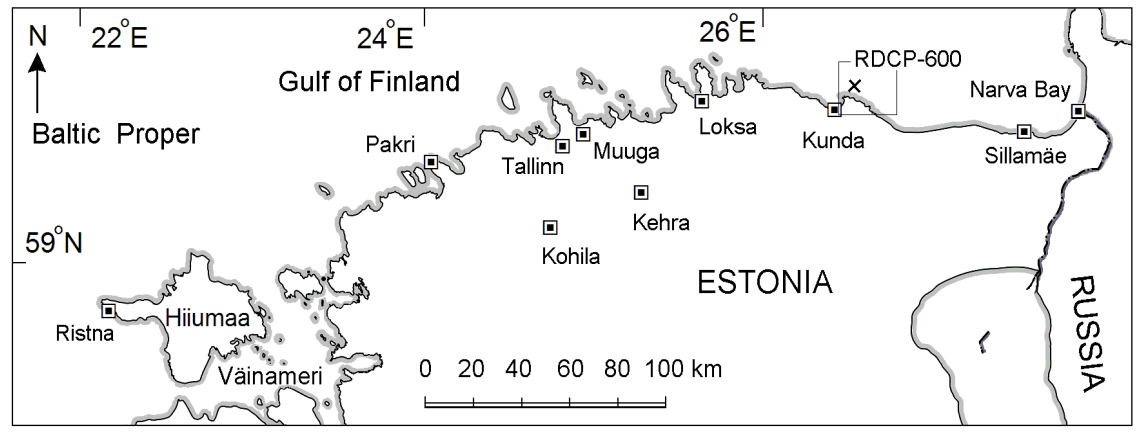

Figure 1: The study area. The Estonian Cell pulp mill locates $10 \mathrm{~km}$ to the east of Kunda town; the sewage outlet and monitoring stations are clustered around the RDCP-600 mooring site. 
In the Kunda region, the major pollution source was the large Kunda cement factory, however, the emission of the factory has considerably decreased over the recent decade. On the $8^{\text {th }}$ of September 2006, AS Estonian Cell, a brand new aspen pulp mill, was officially opened near Kunda. The project with a total cost of about 160 million Euros was the second largest foreign investment into Estonian industry and the factory was welcomed as it provides stable employment for about 100 people. In Estonia, the large Soviet-era cellulose and paper factories were either closed or reequipped in 1990s and since then there is a considerable reluctance to opening of new ones. Partly due to ill memories of past environmental problems in the region, the environmental standards for the plant were set very high. The factory features sulphur free production, chlorine free bleaching and low fresh water consumption. The mill is designed with an annual capacity of 140000 tons of aspen pulp, which is raw material for high quality paper and tissue. Also, high requirements were set on water treatment and environmental monitoring.

The plant's biological water treatment facility was a major investment with a cost of 10 million Euros. It allows both Biological Oxygen Demand (BOD) and Chemical Oxygen Demand (COD) purification level of over 90\%, which is among the highest in this branch of industry. The purified wastewater is conducted via a $9.5 \mathrm{~km}$ long pipe into the Baltic Sea at a depth of $10 \mathrm{~m}$ and about $1.5 \mathrm{~km}$ from the coast. Still, an extensive monitoring of the possible effects of the effluents was launched, which is carried out by the Estonian Marine Institute, University of Tartu.

\section{Material and methods}

\subsection{Hydrodynamics}

For studying the hydrodynamic and dilution regime near Kunda (Fig. 1), a Recording Doppler Current Profiler RDCP-600 from AADI Aanderaa Instruments was used. The device was deployed to the seabed by divers at the location of $59.561^{\circ} \mathrm{N}, 26.672^{\circ} \mathrm{E}$, about $1.5 \mathrm{~km}$ offshore, not far from the pipe's outlet. The upward-looking instrument was deployed at the depth of $12 \mathrm{~m}$ during two periods: between 10 August and 14 September, and 16 October and 24 November 2006. Flow data from six depth layers were obtained. The RDCP is also equipped with a temperature, turbidity and conductivity sensor, as well as a pressure sensor for measuring both the relative sea level variations and wave parameters. Atmospheric forcing conditions were studied throughout 2005-2007 on the basis of routine data obtained from Kunda and Pakri meteorological stations. Some preliminary hydrodynamic simulations were performed using SUMMERI-simulator and a 3D hydrodynamic model.

\subsection{Hydrochemistry and biota sampling}

Monitoring cruises and in situ measurements included CTD-probing and water samplings along the northern coast of Estonia. The CTD-profiling was 
performed using Seabird-19 and SAIV-205 probes at three stations (with depths of 10,11 and $20 \mathrm{~m}$ ). Vertical profiles of water temperature, salinity, oxygen and fluorescence were measured. At the same time, surface water samples for Ntot, Ptot, $\mathrm{pH}, \mathrm{BOD}_{7}, \mathrm{COD}$ and suspended matter were taken. The samples were analysed in the certified Pärnu laboratory of the Estonian Marine Institute. Monitoring of bottom habitat was performed annually along two transects on the both sides of the pipe. Samples of phytoplankton, zooplankton and Chl $a$ were taken during regular monitoring surveys.

In order to obtain data on background conditions, the monitoring began one year prior to the opening of the plant, i.e. in July 2005. In 2006, the regular surveys took place on 27 May, 27 June, 23 July, 8 August, 14 September and 5 October. In 2007 they were carried out on 24 April, 29 May, 26 June, 30 July, 8 August, 29 September, 11 October and 14 December (see also Table 1).

\section{Results and discussion}

\subsection{Discharges}

Starting from the series of trial production, which began in March-April 2006, the wastewater discharges (D) have been quite constant at an average level of $5200 \mathrm{~m}^{3} /$ day or $157000 \mathrm{~m}^{3}$ per month (Fig. 2a).

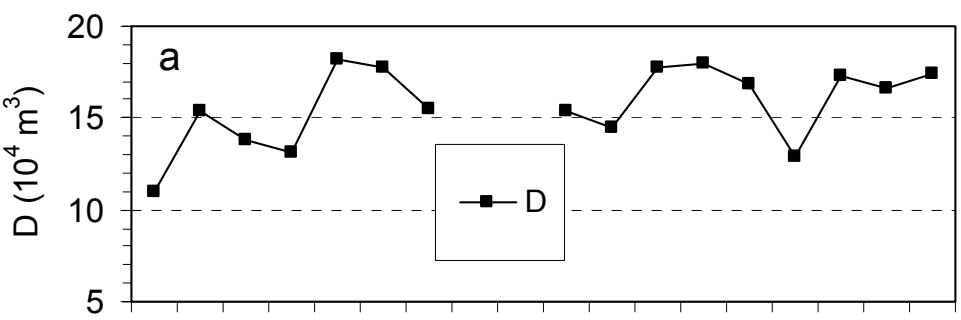

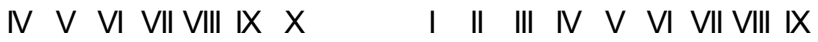

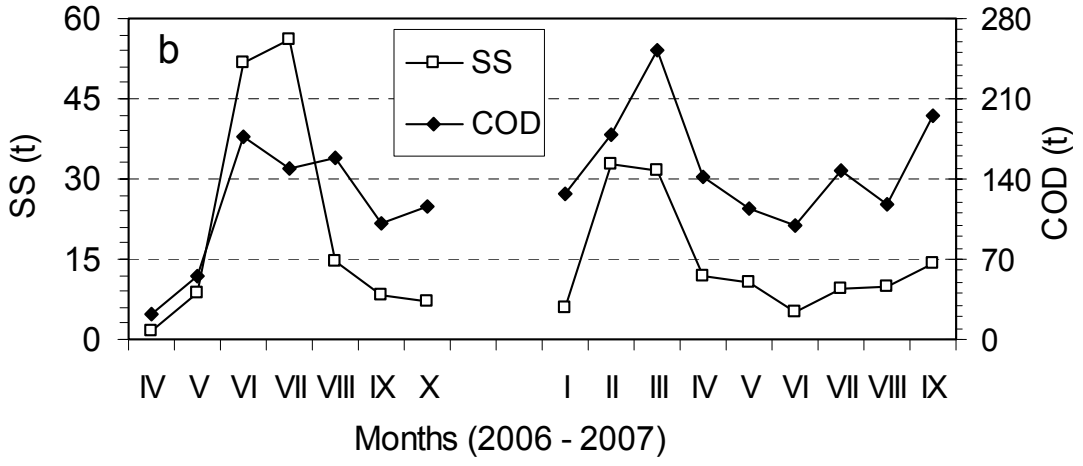

Figure 2: Monthly discharges of effluents (D, $\left.10^{4} \mathrm{~m}^{3}\right)$, suspended solids (SS, t), and Chemical Oxygen Demand (COD, t) in 2006 and 2007. 
If the first month (April 2006) is omitted, the discharges of suspended solids (SS) have varied in a great deal between 6 and 56 tonnes per month with a maximum daily discharge of $10.5 \mathrm{t}$ on 21 June 2006. Monthly discharges of COD fluctuated roughly between 100 and $200 \mathrm{t}$ (Fig. 2b) with a daily maximum of 25 tonnes on 23 July 2006.

The largest variation coefficient, calculated on the basis of daily discharge data, is in SS (1.7). The coefficient for COD is 0.69 and for D is 0.27 . The average concentration of SS discharged from the pipe outlet to the sea is 110 $\mathrm{mg} / \mathrm{l}$ and the average concentration of COD discharges is $850 \mathrm{mg} / \mathrm{l}$. They both are well over the natural background of the Gulf of Finland, which was determined during the previous surveys [7] (see also Table 1). The location of the outlet should ensure good hydrodynamic dilution conditions for discharges. Indeed, while the fluid effluents were reasonably well controlled in 2006-2007, occasionally some problems rose with organoleptic pollution of open air, which originated from the sludge depository on the factory's territory.

Table 1: Measured hydrochemical variables during monitoring cruises. Each value represents an average for three adjacent stations, which are located within $1 \mathrm{~km}$ radius of the outlet.

\begin{tabular}{|l|c|c|c|c|c|c|}
\hline Survey & $\begin{array}{c}\mathrm{SS} \\
(\mathrm{mg} / \mathrm{l})\end{array}$ & $\mathrm{pH}$ & $\begin{array}{c}\mathrm{COD} \\
(\mathrm{mgO} / \mathrm{l})\end{array}$ & $\begin{array}{c}\mathrm{BOD}_{7} \\
(\mathrm{mgO} / \mathrm{l})\end{array}$ & $\begin{array}{c}\mathrm{N}_{\mathrm{t}} \\
(\mu \mathrm{molN} / \mathrm{l})\end{array}$ & $\begin{array}{c}\mathrm{P}_{\mathrm{t}} \\
(\mu \mathrm{molP} / \mathrm{l})\end{array}$ \\
\hline 12.07 .05 & 6.2 & & 105 & 1.9 & 30 & 0.91 \\
\hline 27.05 .06 & 8.6 & & 45 & 2.1 & & \\
\hline 27.06 .06 & 5.3 & 8.0 & 54 & 1.8 & & \\
\hline 23.07 .06 & 9.1 & 8.3 & 79 & 1.8 & 13.3 & 0.78 \\
\hline 10.08 .06 & 8.6 & 7.3 & 37 & 1.5 & 25.3 & 1.48 \\
\hline 13.09 .06 & 9.5 & 7.7 & 29 & 3.3 & 38.6 & 0.73 \\
\hline 05.10 .06 & 2.0 & 7.8 & & 1.2 & & 0.54 \\
\hline 24.04 .07 & 16.3 & & 71 & 3.7 & 33.2 & 1.45 \\
\hline 29.05 .07 & 10.0 & & 53 & 2.0 & 33.7 & 1.19 \\
\hline 26.06 .07 & 14.6 & & 54 & 1.8 & 33.0 & 0.9 \\
\hline 30.07 .07 & 8.0 & & 75 & 1.1 & 32.7 & 0.86 \\
\hline 08.08 .07 & 11.3 & & 79 & 1.9 & 32.8 & 0.95 \\
\hline 29.09 .07 & 7.5 & & 44 & 0.7 & 29.6 & 1.81 \\
\hline 11.10 .07 & 4.5 & & 36 & 0.7 & 33.8 & 1.30 \\
\hline 14.12 .07 & 8.3 & & 79 & 0.7 & 32.8 & 1.48 \\
\hline
\end{tabular}

\subsection{Near-shore hydrodynamic conditions}

During the hydrodynamic investigations in 2006 (Figs. 3,4), the meteorological conditions were rather peculiar. Persistent eastwinds with moderate strength dominated in July and in the first half of August (Fig. 3a). Nevertheless, the current velocity near the pipe outlet reached $60 \mathrm{~cm} / \mathrm{s}$. The westward alongshore flow appeared as a coastal jet, which was visible in the upper $6 \mathrm{~m}$ layer (Fig. 3b). As a result, upwelling of cold (Fig. 3c) and more saline water occurred. 

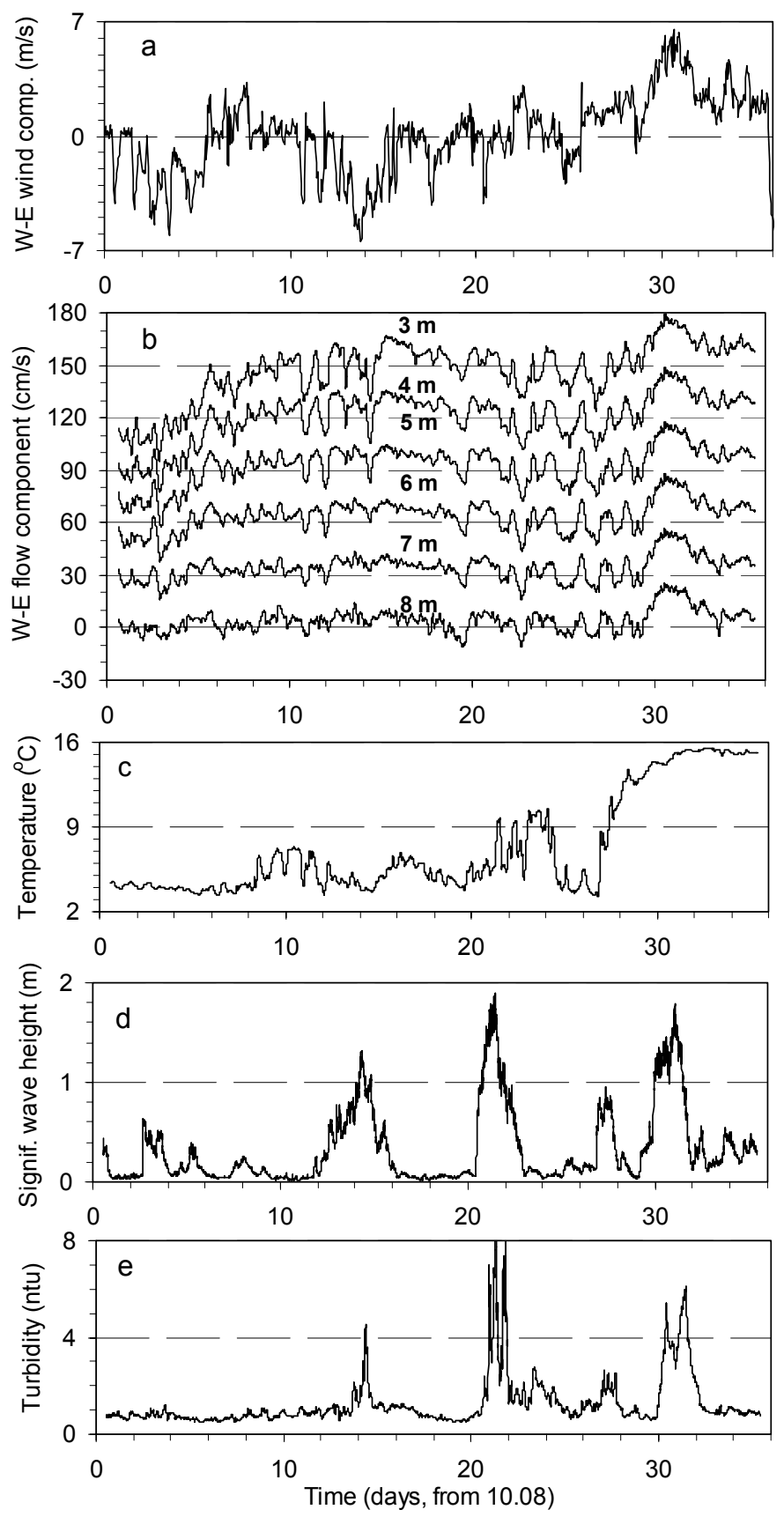

Figure 3: Wind (a) and current speed (b, offsets of $30 \mathrm{~cm} / \mathrm{s}$ are added to the series of consecutive depth layers), water temperature (c), wave height (d) and turbidity (e) from 10 August - 14 September 2006. 

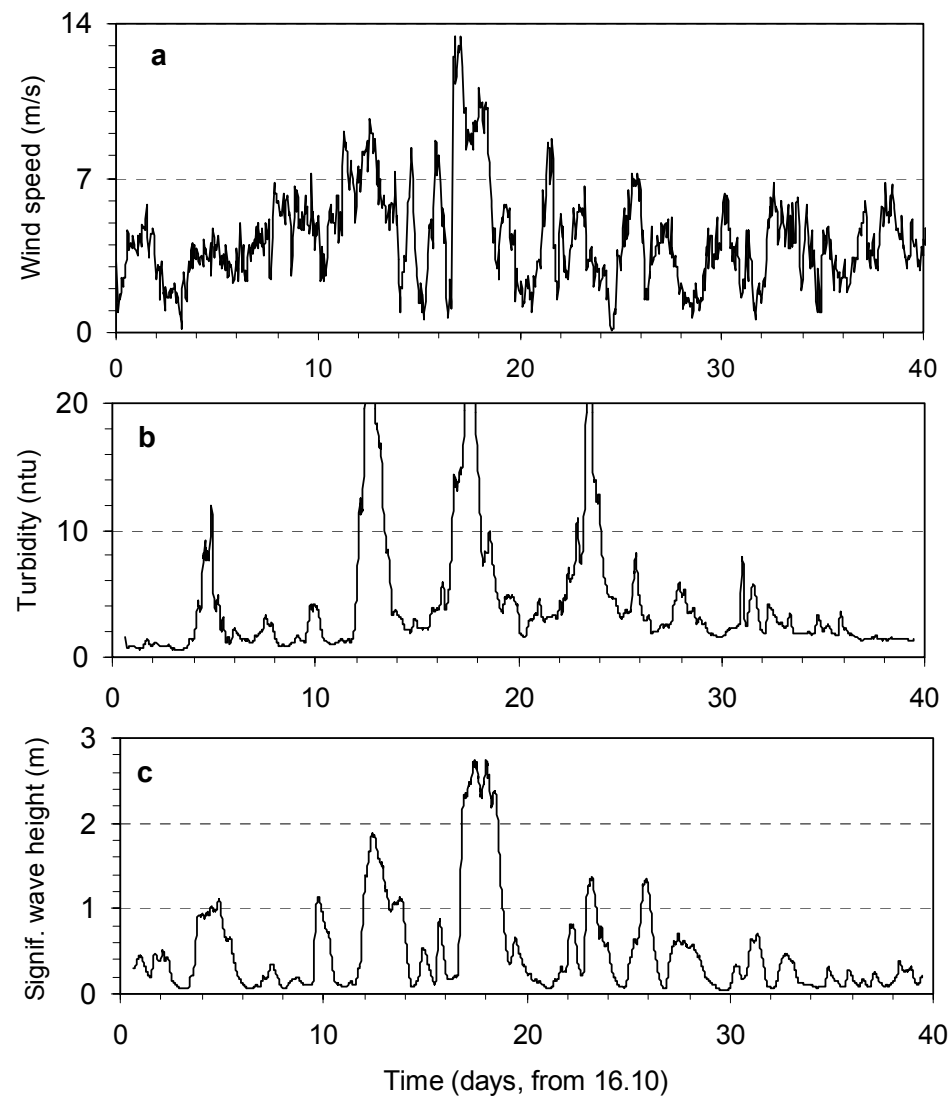

Figure 4: Wind speed (a), water turbidity (b) and wave height (c) for the period 16 October - 24 November 2006.

Upwelling along the straight section of the North Estonian coast was detectable both from the sea surface temperature recordings and corresponding satellite images [8], as well as from the stratified vertical structure of measured hydrological and chemical variables (Figs. 3b,5). Starting from the $31^{\text {st }}$ of August, the event began to fade due to change in wind conditions. Strong wave activity with significant wave height of up to $2 \mathrm{~m}$ (Fig. $3 \mathrm{~d}$; max wave height 3.1 $\mathrm{m}$ ) and vertical mixing during westerly stormwinds (gusts up to $25.5 \mathrm{~m} / \mathrm{s}$ ) dispersed the event.

An important implication tells us that in certain upwelling-forming wind conditions, relatively modest eastwinds can produce a surprisingly fast westward coastal jet. The width of the stream can be only a few kilometres, but the velocity can reach up to $1 \mathrm{~m} / \mathrm{s}$ in the thin upper layer. This, in case of hypothetical accident spills either in the pulp mill or in nearby ports of Kunda and Sillamäe, can transport pollution fast and far. In addition, the upwelling-associated 
extremely low seawater temperatures (e.g. as low as $4^{\circ} \mathrm{C}$ in July 2006) may prohibit biochemical decomposition processes.

In autumn, westerlies dominated, which is quite typical for the region for that season (Fig. 4). A vertically homogeneous eastward current of up to $50 \mathrm{~cm} / \mathrm{s}$ occurred. The second important implication appears from Fig. 3d,e and Fig. 4: Variations in turbidity (and in $\mathrm{P}_{\text {tot }}$ as well [9]) in the near-shore (up to depth of $15 \mathrm{~m}$ ) is mainly associated with wave action during storms. The influence of this natural resuspension process is far more pronounced, than the influx of SS through the pipe. This was also confirmed by satellite images [10].

It appeared from the hydrodynamic modelling runs, that the volume of the effluents was not large enough to alter circulation conditions in the coastal sea. Good dilution conditions due to currents and wave action prevailed and anthropogenic changes in hydrochemical or -biological conditions should be looked for in the vicinity of the sewage outlet only.

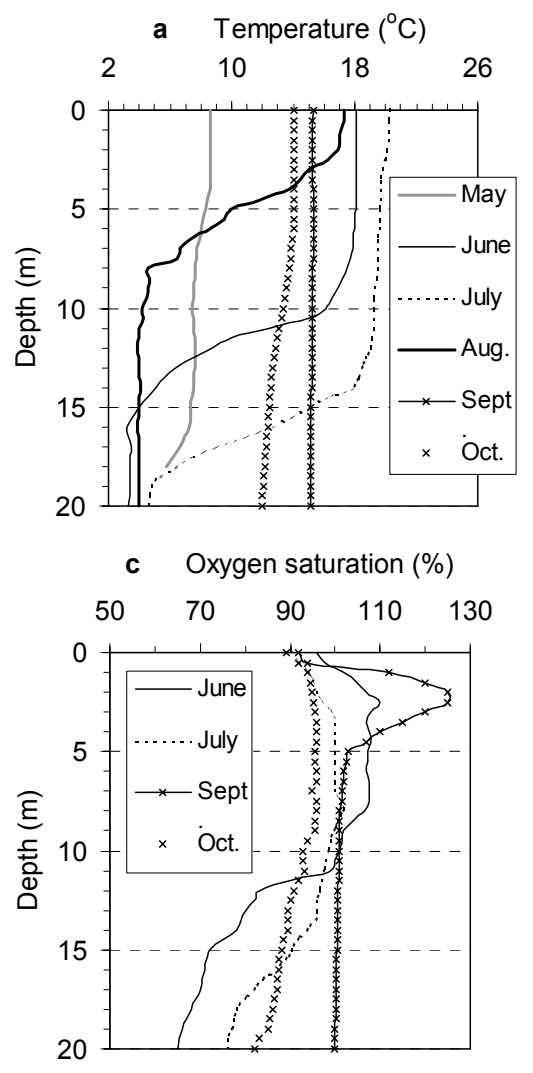

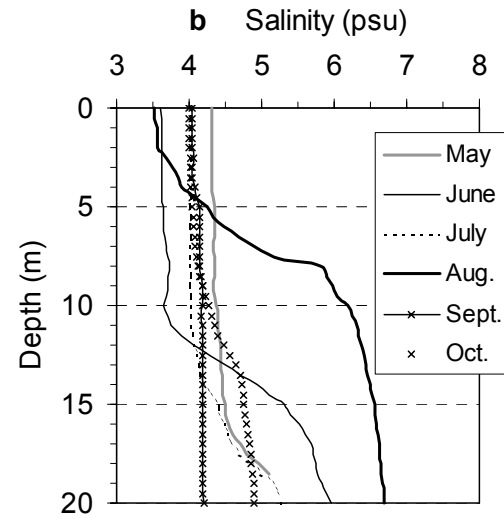

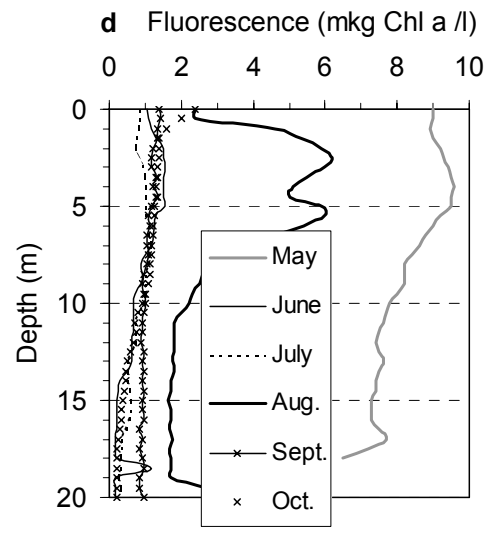

Figure 5: Vertical profiles of temperature (a), salinity (b), oxygen (c) and fluorescence (d) in 2006. The profiles of August represent upwelling. 


\subsection{Results of hydrochemical and biological monitoring}

The results of hydrochemical monitoring show substantial natural variability, where, in most cases, an anthropogeneous signal is hardly detectable (Table 1, Fig. 5). The nutrient concentrations show natural seasonality and some here unidentified variability. Variation in SS largely appears due to meteorologically evoked resuspension, which include events both in synoptic scale and in the frequency of those events over seasonal course. The concentrations of nutrients and other measured parameters seem to be a bit higher than in the open Gulf of Finland, but still lower than in some other areas along the North Estonian coast in the vicinity of the Narva River mouth, near Sillamäe and in the Muuga Bay $[6,7]$.

Obviously, due to low water consumption and the up-to-date purification technology, the pollution discharges from the wastewater treatment plant of the pulp mill to the sea are not large. On the other hand, owing to good natural dilution conditions, the impact of discharges on the abiotic environmental components is relatively modest as well.

However, according to the biological surveys, there may be small changes in bottom vegetation and zoobenthos in the very vicinity of the outlet [7]. The discharged SS may impair underwater light conditions and settling may bury benthic organisms [11], but the study period has been too short so far and the effects are just barely visible. No significant changes were detected neither in phytoplankton, nor zooplankton communities near the outlet.

\section{Conclusions}

1) The preliminary results basically confirm that the impact of the pulp mill on the coastal sea is modest and the environmental risks are well handled. The discharges from the plant to the sea are not large and due to good hydrodynamic dilution conditions, the impact on the abiotic environmental components is barely visible on the background of normal seasonal and short-scale variability. For example, the influence of natural resuspension process during storms is far more pronounced, than the influx of SS or $\mathrm{P}_{\text {tot }}$ through the pipe.

2) It appeared from the flow measurements with RDCP that during favourable wind conditions, upwelling and coastal jet could evolve along this section of coast. This, in case of hypothetical accident spills either in the pulp mill or in nearby ports, can rapidly transport the pollution to a large distance. Associated with upwelling extremely low water temperatures may prohibit biochemical decomposition processes.

3) No significant changes were detected neither in phytoplankton, nor zooplankton communities near the outlet. There may be small changes in bottom organisms in the vicinity of the outlet, possibly due to slightly deteriorated light conditions and settling. However, the study period is rather short so far and the monitoring activities are still ongoing. 


\section{Acknowledgements}

The monitoring was financed by Estonian Cell AS and was performed by the Estonian Marine Institute, University of Tartu. The study was also supported by the Estonian Science Foundation through grant No 7609.

\section{References}

[1] Suursaar, Ü., Estonian marine monitoring 1968-1991: Results and evaluation. Finnish Marine Research, 262, pp. 123-134, 1994.

[2] Wulff, F., Rahm, L., Jonsson, P., Brydsten, L., Ahl, T. \& Granmo, A., A mass-balance model of chlorinated organic matter for the Baltic Sea - a challenge for ecotoxicology. Ambio, 22, pp. 27-31, 1993.

[3] Balk, L., Förlin, L., Söderström M. \& Larsson, Å., Indications of regional and large-scale biological effects caused by bleached pulp mill effluents. Chemosphere, 27, pp. 631-650, 1993.

[4] Kankaanpää, H., Lauren, M., Saares, R., Heitto, L. \& Suursaar, Ü., Distribution of halogenated organic material in sediments from anthropogenic and natural sources in the Gulf of Finland catchment area. Environmental Science and Technology, 31, pp. 96-104, 1997.

[5] HELCOM, The Fourth Baltic Sea Pollution Load Compilation (PLC-4). Balt. Sea Environ. Proc., 93, Helsinki, 2004.

[6] Suursaar, Ü., Astok, V. \& Kotta, J., Monitoring and assessment of the Estonian coastal sea in 1945-2003. Water protection of the Gulf of Finland and Estonian waterbodies (1945-2003), ed. H.-A. Velner, TUT Press: Tallinn, pp. 129-144, 2005.

[7] Aps, R., (ed). Monitoring of the coastal sea in the region of Kunda pulp mill in 2006. Manuscript in the Library of the Estonian Marine Institute, Tallinn, 2006.

[8] Suursaar, Ü. \& Aps, R., Spatio-temporal variations of hydrophysical and chemical parameters during a major upwelling event in the southern coast of the Gulf of Finland in the summer of 2006. Oceanologia, 49, pp. 209228, 2007.

[9] Suursaar, Ü., Kullas, T. \& Otsmann, M., The influence of currents and waves on ecological conditions of the Väinameri. Proceedings of the Estonian Academy of Sciences. Biology, Ecology, 50, pp. 231-247, 2001.

[10] Kutser, T., Metsamaa, L., Vahtmäe, E. \& Aps, R., Operative monitoring of the extent of dredging plumes in coastal ecosystems using MODIS satellite imagery. Journal of Coastal Research, SI50, pp. 180-184, 2007.

[11] Kotta, J., Lauringson, V. \& Kotta, I., Response of zoobenthic communities to changing eutrophication in the northern Baltic Sea. Hydrobiologia, 580, pp. 97-108, 2007. 